\title{
Ocena wartości badania ultrasonograficznego metodą Dopplera w diagnostyce ostrej moszny u chłopców
}

\section{Assessment of the validity of Doppler sonography in the diagnosis of acute scrotum in boys}

\author{
Jacek Materny¹, Marta Dymny², Laura Lesiewska², Elżbieta Gawrych¹ \\ ${ }^{1}$ Klinika Chirurgii Dziecięcej i Onkologicznej Pomorskiego Uniwersytetu Medycznego w Szczecinie \\ ul. Unii Lubelskiej 1, 71-252 Szczecin \\ Kierownik: prof. dr hab. n. med. Elżbieta Gawrych \\ ${ }^{2}$ Studenckie Koło Naukowe przy Klinice Chirurgii Dziecięcej i Onkologicznej Pomorskiego Uniwersytetu Medycznego w Szczecinie \\ ul. Unii Lubelskiej 1, 71-252 Szczecin \\ Opiekun: dr n. med. Jacek Materny
}

\section{SUMMARY}

Purpose: Comparison of preoperative scrotal Doppler sonography and final diagnosis of subsequent exploration in patients with acute scrotum.

Material and methods: Retrospective analysis of the medical history of 61 patients operated on in The Department of Paediatric and Oncological Surgery in Szczecin in 2008-2014.

Results: Mean patient age (years) with testicular torsion was $12.7 \pm 4.0$, with torsion of a testicular appendage was $8.6 \pm 4.5$, and with orchitis or epididymitis was $7.2 \pm 8.5$. During operation we diagnosed testicular torsion in 28 (45\%) patients, torsion of the

\section{STRESZCZENIE}

Wstęp: Celem pracy było porównanie obrazu ultrasonograficznego ostrej moszny u dzieci ze zmianami stwierdzonymi śródoperacyjnie oraz ocena czułości badania ultrasonograficznego w diagnostyce ostrej moszny u dzieci.

Materiał i metody: Retrospektywnej analizie poddano dokumentację medyczną 61 dzieci leczonych w Klinice Chirurgii Dziecięcej i Onkologicznej Pomorskiego Uniwersytetu Medycznego w Szczecinie (PUM) w latach 2008-2014 z powodu zespołu ostrej moszny, u których wykonano rewizję operacyjną moszny, bez względu na wynik badania ultrasonograficznego.

Wyniki: Średni wiek operowanych wyniósł dla chłopców ze skrętem jądra $12,7 \pm 4,0$, skrętem przyczepka jądra 8,6 $\pm 4,5$ testicular appendage in 26 (43\%), and orchitis or epididymitis in 7 (12\%). The specificity of Doppler sonography for testicular torsion was $46 \%$, for torsion testicular appendage $20 \%$, and for orchitis/epididymitis $57 \%$.

Conclusions: Doppler sonography of the scrotum shows limited specificity in the diagnosis of acute scrotum in boys. Surgical exploration is recommended even with apparently normal Doppler sonography examinations.

Key words: acute scrotum, testicular torsion, torsion of the appendix testis, orchitis, ultrasonography.

i stanem zapalnym jądra lub najądrza 7,2 $\pm 8,5$. Śródoperacyjnie stwierdzono skręt jądra u 28 (45\%) pacjentów, skręt przyczepka jądra lub najądrza u 26 (43\%), stan zapalny jądra lub najądrza u 7 (12\%). Czułość badania ultrasonograficznego wyniosła dla skrętu jądra 46\%, skrętu przyczepka jądra bądź najądrza 20\% i stanu zapalnego gonady $57 \%$.

Wnioski: 1. Badanie ultrasonograficzne metodą Dopplera wykazuje ograniczoną czułość w diagnostyce ostrej moszny u dzieci. 2. Rewizja moszny w przypadkach negatywnego wyniku badania ultrasonograficznego wydaje się być uzasadniona w każdym przypadku.

Słowa kluczowe: ostra moszna, skręt jądra, skręt przyczepka jądra, zapalenie jądra, ultrasonografia.

\section{WSTĘP}

Zespół ostrej moszny definiowany jest jako nagły, ostry ból w obrębie moszny z towarzyszącym obrzękiem jej tkanek o różnym nasileniu. W urologii dziecięcej uważany jest za stan wymagający pilnej interwencji chirurgicznej ze względu na możliwość skrętu jądra, a w następstwie ostrego niedokrwienia i zagrożenia utraty gonady. Badanie ultrasonograficzne Dopplera (USG Doppler) jest badaniem obrazowym z wyboru w diagnostyce tego zespołu u dzieci [1]. Wielu autorów dyskutuje na temat wartości rozpoznawczej badania ultrasonograficznego, zwłaszcza w ustaleniu jednoznacznej diagnozy skrętu jądra [2]. Według Sidhu, obraz sonograficzny nie jest „złotym standardem” dla rozpoznania skrętu, a kwalifikacja do leczenia chirurgicznego powinna opierać się przede wszystkim na ocenie stanu klinicznego [3]. W Klinice Chirurgii Dziecięcej i Onkologicznej Pomorskiego Uniwersytetu Medycznego w Szczecinie (PUM) wszyscy pacjenci z objawami zespołu ostrej moszny, zwłaszcza sugerującymi skręt jądra, poddawani są rewizji operacyjnej moszny bez względu na wynik badania obrazowego.

Celem pracy było porównanie obrazu ultrasonograficznego ostrej moszny u dzieci ze zmianami stwierdzonymi śródoperacyjnie, a także ocena czułości badania ultrasonograficznego w diagnostyce ostrej moszny u chłopców. Spodziewano się uzyskać odpowiedź na pytanie, czy kryteria dotyczące 
kwalifikacji do leczenia operacyjnego bez względu na wynik badania USG są słuszne.

\section{MATERIA I METODY}

Retrospektywnej analizie poddano dokumentację 264 dzieci operowanych w Klinice Chirurgii Dziecięcej i Onkologicznej PUM w latach 2008-2014 z powodu objawów klinicznych sugerujących zespół ostrej moszny. Z analizy wykluczono pacjentów zakwalifikowanych do leczenia operacyjnego bez przedoperacyjnego badania USG oraz z niepełną dokumentacja medyczną. Ostateczny materiał badawczy stanowiła dokumentacja medyczna 61 dzieci. Ocenie poddano wiek chorych, czas trwania i charakter objawów klinicznych oraz dokumentację obrazową badania USG Doppler.

Typowe objawy dla skrętu jądra zdefiniowano wg Karmazyn i wsp. jako nagły ból jądra trwający krócej niż 6 godz. i/lub powiększone bolesne jądro, i/lub brak/osłabienia odruchu dźwigacza jądra, i/lub podciągniecie jądra [4]. Typowe objawy dla skrętu przyczepka jądra zdefiniowano wg Yin i Trainor jako nagły ból w obrębie moszny i/lub bolesność górnego bieguna jądra, i/lub obecność czarnej plamki w górnym biegunie moszny [5]. Typowe objawy dla zapalenia jądra lub najądrza zdefiniowano wg Kadish i Bolte jako ból jądra, zwłaszcza jego górnego bieguna, i/lub naciek zapalny w obrębie moszny, i/lub obecność dodatniego objawu Prehn's, polegającego na zmniejszeniu bólu przy podniesieniu jądra [6]. Przedoperacyjne badanie USG Doppler wykonano w Zakładzie Radiodiagnostyki i Radiologii Interwencyjnej w Szczecinie u wszystkich pacjentów z badanej grupy. Typowe objawy skrętu jądra w badaniu obrazowym określono wg kryteriów ustalonych przez Lin i wsp. jako brak przepływu tętniczego i żylnego lub zmniejszenie prędkości przepływu w skręconym jądrze oraz zwiększenie wskaźnika RI (resistive index) - rycina 1. Za typowe objawy skrętu przyczepka przyjęto zwiększenie jego wymiarów powyżej $5 \mathrm{~mm}$ i/lub owalny kształt, i/lub zwiększenie przepływów wokół przyczepka [7]. Według Waldert i wsp., zwiększenie perfuzji w powiększonym jądrze lub najądrzu w badaniu USG Doppler jest charakterystycznym objawem zapalania jądra lub najądrza [1].

Wszyscy chłopcy byli leczeni chirurgicznie bez względu na wynik badania ultrasonograficznego. Mosznę otwierano $\mathrm{z}$ dostępu poprzecznego. W przypadku stwierdzenia martwiczo

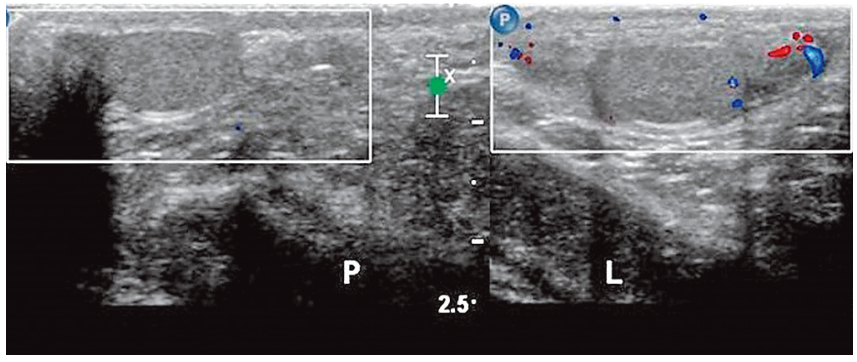

RYCINA 1. Brak przepływów naczyniowych w USG Doppler jądra prawego przed leczeniem operacyjnym zmienionego skręconego przyczepka jądra lub najądrza wykonywano jego resekcję z warstwowym zamknięciem osłonek moszny. Jeżeli stwierdzono skręt jądra, dokonywano jego odkręcenia i oceniano ukrwienie. W przypadkach wątpliwych nacinano osłonkę białawą, a przy braku perfuzji jądro usuwano. Natomiast jeśli zaobserwowano powrót ukrwienia, jądro umocowywano w mosznie 3 szwami do osłonki białawej. Pełny skręt jądra zdefiniowano wg Frush $i$ wsp. jako skręt powrózka obejmujący więcej niż $360^{\circ}$, niepełny skręt - jeżeli mniej niż $360^{\circ}$ [8]. Przeciwległe jądro profilaktycznie umocowywano szwem jednoczasowo bądź w terminie późniejszym, zabezpieczając przed ewentualnym skrętem. W analizie statystycznej zastosowano testy nieparametryczne. Za poziom istotności statystycznej przyjęto $\mathrm{p}<0,05$.

\section{WYNIKI}

Średni wiek wszystkich operowanych chłopców wyniósł $10,4 \pm 5,3$ lat, przy czym operowanych z powodu skrętu jądra $-12,7 \pm 4$, skrętu przyczepka - 8,6 $\pm 4,5$ i zapalenia najądrza $7,2 \pm 8,5$. Stwierdzono istotną statystycznie różnicę pomiędzy wiekiem chłopców operowanych z powodu skrętu jądra i skrętu przyczepka $(\mathrm{p}=0,0004)$ oraz brak znamienności statystycznej pomiędzy chłopcami operowanymi z powodu skrętu jądra i operowanymi z powodu stanu zapalnego $(p=0,26)$. Średni czas trwania objawów klinicznych do chwili operacyjnej rewizji moszny wyniósł dla wszystkich grup $32 \pm 24$ godz. Czas trwania objawów u chłopców ze skrętem jądra był istotnie krótszy $(p=0,05)$ w porównaniu do pacjentów ze skrętem przyczepka lub stanu zapalnego jądra bądź najądrza i wyniósł odpowiednio $21 \pm 24,41 \pm 30,46 \pm 24$. Typowe objawy kliniczne skrętu jądra stwierdzono u 18 z 28 (64\%), skrętu przyczepka u 17 z 26 (65\%). Typowy obraz skrętu jądra w badaniu USG Doppler stwierdzono u 13 na 28 operowanych, skrętu przyczepka u 5 na 26, a zapalenia jądra lub najądrza u 4 na 7.

U wszystkich pacjentów wykonano rewizję moszny bez względu na wynik badania obrazowego. Śródoperacyjnie stwierdzono skręt jądra u 28 (45\%), skręt przyczepka u 26 (43\%) i zapalenie jądra bądź najądrza u 7 (12\%). W każdym przypadku skrętu przyczepka obserwowano zmiany martwicze w jego tkance i wykonywano resekcję przyczepka (ryc. 2).

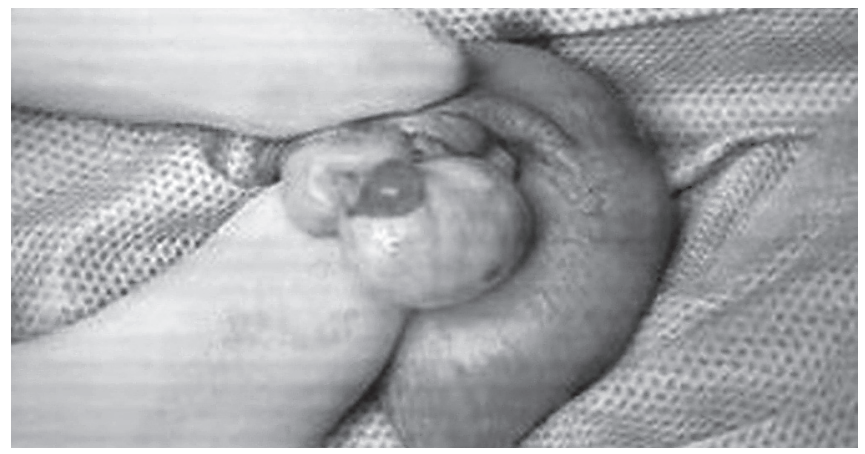

RYCINA 2. Skręt przyczepka jądra - obraz śródoperacyjny 

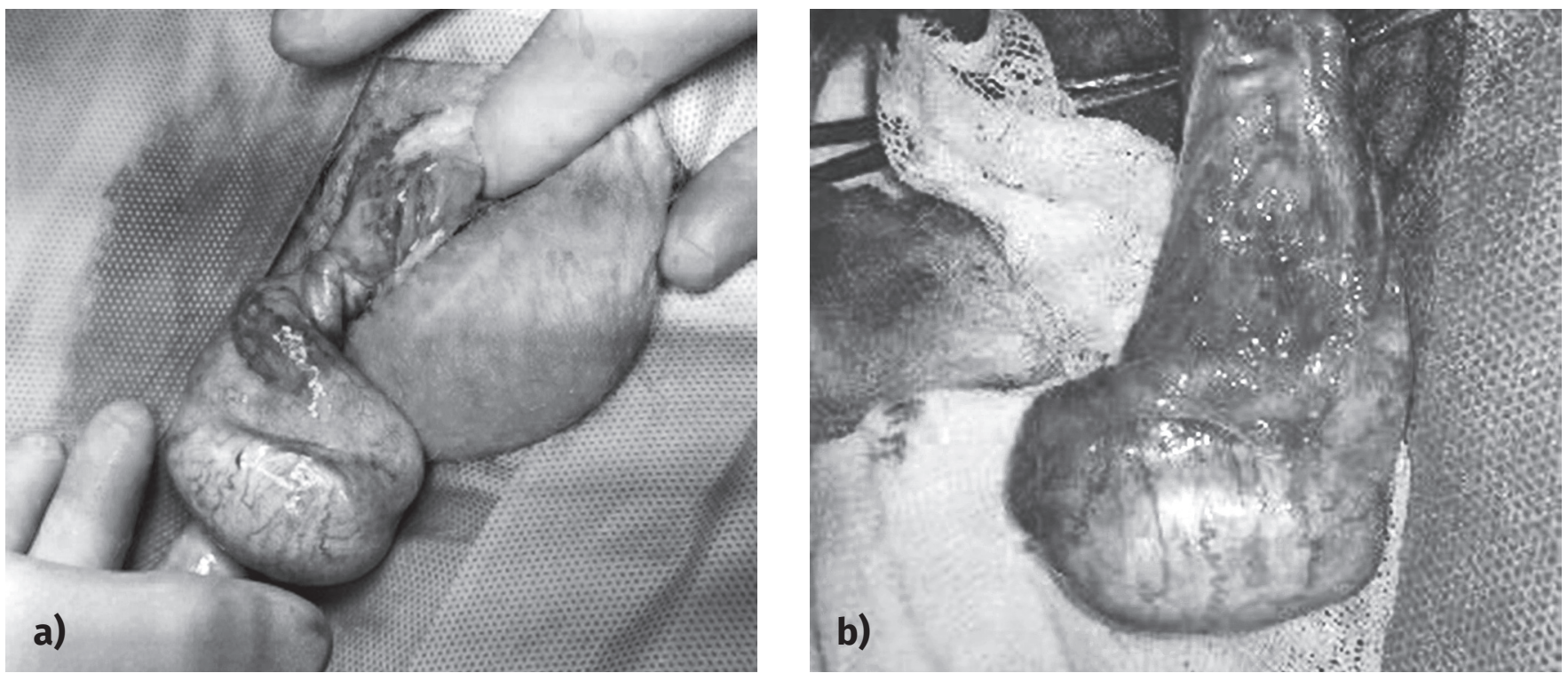

RYCINA 3. Skręt jądra - obraz śródoperacyjny: a) przed odkręceniem - niedokrwienie jądra; b) po odkręceniu - powrót ukrwienia

W tej grupie u 16 chorych stwierdzono obecność dodatkowych ale nieskręconych przyczepów, które również usuwano. Pełny skręt jądra, trwający do 6 godz., stwierdzono u 15 na 28 operowanych (54\%). W żadnym przypadku nie doprowadził on do martwicy gonady, nie było zatem wskazań do jej usunięcia. Niepełny skręt jądra stwierdzono u pozostałych 13 (46\%), u których gonada została zachowana (ryc. 3a i 3b), u 12 gonadę po odkręceniu umocowano w mosznie, a u jednego fiksacja dotyczyła obu gonad. U pozostałych umocowanie drugiego jądra wykonano w terminie odroczonym, zabezpieczając przed ewentualnym skrętem. Czułość badania ultrasonograficznego wyniosła w przypadku skrętu jądra 46\%, skrętu przyczepka $20 \%$ i zapalenia jądra lub najądrza 57\%. Stwierdzono, iż czułość badania ultrasonograficznego była znacząco niższa $(p=0,03)$ u chorych z niepełnym skrętem lub spontanicznym odkręceniem. Średni czas hospitalizacji wyniósł $3 \pm 2,9$ dnia.

\section{DYSKUSJA}

Zespół ostrej moszny należy do schorzeń wymagających pilnej interwencji chirurgicznej i stanowi wyzwanie zarówno dla chirurga dziecięcego, jak i radiologa, ponieważ nierozpoznanie skrętu jądra bądź odroczenie operacji może wiązać się z utratą gonady [1]. Pewne, wstępne rozpoznanie stanu zapalnego gonady nie wymaga leczenia operacyjnego, jedynie stosowania antybiotykoterapii. Pewne rozpoznanie skrętu przyczepka jest względnym wskazaniem do interwencji operacyjnej. Uważa się, że skręcony przyczepek może ulec samoamputacji, nie wpływając na stan gonady, bądź można go usunąć chirurgicznie w trybie odroczonym [3]. Częstość występowania skrętu jądra ocenia się na 4,5/100 000 chłopców poniżej 25. r.ż., jej wzrost obserwuje się w okresie dojrzewania, kiedy objętość jądra ulega znacznemu powiększeniu [9]. W badaniach wieloośrodkowych stwierdzono, że skręt jądra stanowi 22,6\% wszystkich przypadków ostrej moszny [10].
Karmazyn i wsp. definiują typowe objawy skrętu jądra jako nagły ból trwający krócej niż 6 godz. i/lub powiększone bolesne jądro, i/lub brak/osłabienie odruchu dźwigacza jądra, i/lub podciągniecie jądra [4]. Według Rabinowitz, brak odruchu dźwigacza jądra pozwala w $100 \%$ rozpoznać skręt jądra [11]. Inni autorzy nie potwierdzili tej zależności w swoim materiale [5, 12]. Kontrowersje dotyczą również dolegliwości bólowych jądra. Objaw ten był obecny u wszystkich chłopców w doniesieniu Kadish i Bolte [6] i u 90\% w opracowaniu Karmazyn i wsp. [4]. Według analizy wyników własnych badanie kliniczne nie zawsze jest jednoznaczne w rozpoznaniu skrętu jądra. Tylko u $64 \%$ badanych pacjentów stwierdzono typowe objawy skrętu jądra w badaniu klinicznym, a u pozostałych rozpoznanie ustalone zostało śródoperacyjnie. Inni autorzy potwierdzają brak rozpoznania skrętu jądra w badaniu przedmiotowym u 10-30\% chłopców [13]. Ponieważ same objawy kliniczne mogą być niewystarczające w diagnostyce ostrej moszny u dzieci, wielu autorów poddało analizie wartość badania USG Doppler w ustaleniu rozpoznania. W analizowanym materiale skręt jądra w badaniu USG rozpoznano u 13/28 pacjentów. Niską rozpoznawalność należy wiązać z niekorzystnym działaniem niektórych czynników wpływających na przebieg badania. Duży wpływ na prawidłową interpretację wyniku badania USG ma doświadczenie wykonującego badanie, trudności w ocenie przepływu w małych jądrach oraz różnorodność anatomiczna skrętu (niepełny, przemijający skręt), a także niepokój dziecka w czasie przeprowadzania badania [3]. Prace eksperymentalne wykazały całkowity brak przepływu przy skręcie jądra o $540^{\circ}$ oraz zmniejszenie przepływu przy skręcie o $360^{\circ}$ [8]. W analizowanym materiale u 13 (46\%) chłopców ze skrętem jądra zaobserwowano sródoperacyjnie niepełny bądź przemijający skręt (samoistne odkręcenie). Stwierdzono istotną statystycznie zależność (wartość współczynnika korelacji Pearsona 0,47) pomiędzy sródoperacyjnie stwierdzonym niepełnym skrętem jądra a fałszywie ujemnym wynikiem badania USG. W świetle spostrzeżeń Patriquin i wsp. zmiany niedokrwienne w jądrze 
pojawiają się po 2 godz. pełnego skrętu, po 6 godz. niedokrwienie staje się nieodwracalne, a po 24 godz. następuje całkowita martwica jądra [14]. W analizowanym materiale średni czas trwania objawów w przypadku skrętu jądra wyniósł $21 \pm 24$ godz. Jednak u 46\% chłopców stwierdzono śródoperacyjnie niepełny lub przemijający skręt jądra z zachowanym ukrwieniem gonady, co tłumaczy brak konieczności jej usunięcia. U chłopców z pełnym skrętem jądra czas trwania objawów był krótszy i wyniósł 4,5 $\pm 2,1$ godz. Podobne wyniki dotyczące czasu, jaki upłynął między początkiem objawów a leczeniem operacyjnym skrętu jądra, uzyskali Waldert i wsp. [1].

Kass i wsp. zaproponowali wyłączną obserwację pacjentów, u których badanie kliniczne nie jest jednoznaczne, a badanie USG Doppler wykazuje prawidłowe lub nieco zmniejszone przepływy naczyniowe [15]. Według różnych autorów, czułość badania USG Doppler w rozpoznaniu skrętu jądra u dzieci mieści się pomiędzy 53-100\%. W materiale Bentley $i$ wsp. spośród 14 dzieci z potwierdzonym śródoperacyjnie skrętem jądra 4 z nich (29\%) miało prawidłowe przepływy w przedoperacyjnym badaniu USG. Jeden z tej grupy wymagał usunięcia gonady z powodu zmian martwiczych powstałych wskutek odroczenia rewizji moszny $[6,16]$. W materiale własnym czułość tego badania była znacznie niższa i wyniosła $46 \%$, co oznacza, że prawie połowa pacjentów z rozpoznanym śródoperacyjnie skrętem jądra miała zachowany prawidłowy przepływ naczyniowy w badaniu USG Doppler, prawdopodobnie ze względu na niepełny lub przemijający skręt gonady.

\section{WNIOSKI}

W analizie wyników własnych wykazano ograniczoną czułość badania USG Doppler w diagnozowaniu zespołu ostrej moszny u chłopców. Wydaje się, że w przypadkach negatywnego bądź wątpliwego wyniku badania sonograficznego rewizja chirurgiczna moszny jest konieczna u każdego pacjenta z objawami klinicznymi sugerującymi ten zespół.

\section{PIŚMIENNICTWO}

1. Waldert M., Klatte T., Schmidbauer J., Remzi M., Lackner J., Marberbger R.: Color Doppler sonography reliably identifies testicular torsion in boys. Pediatr Urol. 2010, 75 (5), 1170-1174.

2. Pepe P., Panella P., Pennisi M., Aragona F.: Does color Doppler sonography improve the clinical assessment of patients with acute scrotum? Eur J Radiol. 2006, 60 (1), 120-124.

3. Sidhu P.S.: Clinical and imaging features of testicular torsion: role of ultrasound. Clin Radiol. 1999, 54 (6), 343-352.

4. Karmazyn B., Steinberg R., Kornreich L., Freud E., Grozovski S., Schwartz M. et al.: Clinical and sonographic criteria of acute scrotum in children: a retrospective study of 172 boys. Pediatr Radiol. 2005, 35 (3), 302-310.

5. Yin S., Trainor J.: Diagnosis and management of testicular torsion, torsion of the appendix testis, and epididymitis. Clin Ped Emerg Med. 2009, 10, 38-44.

6. Kadish H.A., Bolte R.G.: A retrospective review of pediatric patients with epididymitis, testicular torsion, and torsion of testicular appendages. Pediatrics. 1988, 102 (1 Pt 1), 73-76.

7. Lin E.P., Bhatt S., Rubens D.J., Dogra V.S.: Testicular torsion: twists and turns. Semin Ultrasound CT MRI. 2007, 28 (4), 317-328.

8. Frush D.P., Babcock D.S., Lewis A.G., Paltiel H.J., Rupich R., Boke K.E. et al.: Comparison of color Doppler sonography and radionuclide imaging in different degrees of torsion in rabbit testes. Acad Radiol. 1995, 2 (11), 945-951.

9. Mansbach J.M., Forbes P., Peters C.: Testicular torsion and risk factors for orchiectomy. Arch Pediatr Adolesc Med. 2005, 159 (12), 1167-1171.

10. Kalfa N., Veyrac C., Lopez M., Lopez C., Maurel A., Kaselas C. et al.: Multicenter assessment of ultrasound of the spermatic cord in children with acute scrotum. J Urol. 2007, 177 (1), 297-301.

11. Rabinowitz R.: The importance of the cremasteric reflex in acute scrotal swelling in children. J Urol. 1984, 132 (1), 89-90.

12. Sanders L.M., Haber S., Dembner A., Aquino A.: Significance of reversal of diastolic flow in the acute scrotum. J Ultrasound. Med. 1994, 13 (2), 137-139.

13. van Glabeke E., Khairouni A., Larroquet M., Audry G., Gruner M.: Acute scrotal pain in children: results of 543 surgical exploration. Pediatr Surg Int. 1999, 15 (5-6), 353-357.

14. Patriquin H.B., Yazbeck S., Trinh B., Jequier S., Burns P.N., Grignon A. et al.: Testicular torsion in infants and children: diagnosis with Doppler sonography. Radiology. 1993, 188 (3), 781-785.

15. Kass E.J., Stone K.T., Cacciarelli A.A., Mitchell B.: Do all children with an acute scrotum reguire exploration? J Urol. 1993, 150, 667-669.

16. Bentley D.F., Ricchiuti J., Nasrallah F., McMahon R.: Spermatic cord torsion with preserved testis perfusion: initial anatomical observations. J Urol. 2004, 172, 2373-2376. 